\title{
VITAMIN B12-DEFICIENT CHILD OF A VEGAN MOTHER
}

\author{
Olgica B. Milankov ${ }^{* 1,2}$, Milena R. Bjelica ${ }^{1,2}$, Ljiljana Đ. Suvajdžić ${ }^{3}$, Jasmina M. Maksić ${ }^{4}$, Vasja M. \\ Milankov ${ }^{1}$, Deana D. Medić ${ }^{1,5}$, Nebojša M. Ilić \\ ${ }^{1}$ University of Novi Sad, Faculty of Medicine, 21000 Novi Sad, Hajduk Veljkova 3, Serbia \\ ${ }^{2}$ Institute for Child and Youth Health Care of Vojvodina, Department of Paediatrics,21000 Novi Sad, \\ Hajduk Veljkova 10, Serbia \\ ${ }^{3}$ University of Novi Sad, Faculty of Medicine, Department of Pharmacy, 21000 Novi Sad, Hajduk \\ Veljkova 3, Serbia \\ ${ }^{4}$ University of Belgrade, Faculty of Special Education and Rehabilitation, 11000 Belgrade, \\ Studentski trg 1, Serbia \\ ${ }^{5}$ Institute of Public Health of Vojvodina, Center for Microbiology, 21000 Novi Sad, Futoška 121, Serbia \\ ${ }^{6}$ University of Novi Sad, Institute of Food Technology, 21000 Novi Sad, Bulevar Cara Lazara 1, Serbia
}

*Corresponding author:

Phone: +381641376735

E-mail address: olgica.milankov@mf.uns.ac.rs

\begin{abstract}
Vitamin B12 deficiency usually occurs in exclusively breastfed infants whose mothers have pernicious anaemia or are vegetarian. Early treatment of vitamin B12 deficiency in infants can prevent potentially neurologic sequelae. A male child aged 13 months has been hospitalized due to failure to thrive, feeding problems, pallor, weakness and hypotonia. During the pregnancy mother did not eat meat and during lactation she also excluded eggs and milk. The child was exclusively breastfed. Laboratory investigations showed a haemoglobin level of $3.5 \mathrm{~g} / \mathrm{dL}$, haematocrit $10 \%$, red blood cell count of $0.99 \times 10^{12} / \mathrm{L}$, white blood cell count of $4.23 \times 10^{9} / \mathrm{L}$ and platelet count of $55 \times$ $10^{9} / \mathrm{L}$. Vitamin B12 level was low. A bone marrow aspiration finding was consistent with megaloblastic anaemia. The magnetic resonance imaging showed brain atrophy. Vitamin B12 in a dose of 10 $\mu \mathrm{g}$ per $\mathrm{kg}$ was applied intramuscularly daily for 2 weeks, then once weekly. Three days after initiating B12 vitamin therapy there was an improvement in the blood count with the gradual improvement of neurological state. Vitamin B12 deficiency is a treatable cause of pancytopenia and neurological dysfunction in children and should be considered as differential diagnosis in an infant with neurological symptoms.
\end{abstract}

Keywords: megaloblastic anemia, toddler, vegetarian diet, delayed physical development, brain atrophy

\section{INTRODUCTION}

Vitamin B12 (cobalamin) is essential for folate metabolism and DNA synthesis, acting as a cofactor for key enzymatic reactions (Roumeliotis et al., 2012).

Vitamin B12 is not synthesized by the body and must therefore be ingested through diet. In the stomach, it binds to intrinsic factor, a protein synthesized by parietal cells. The B12-intrinsic factor complex is then absorbed into the circula- tion in the distal ileum (Roumeliotis et al. 2012).

Worldwide, vitamin B12 deficiency is an important cause of infant morbidity, especially in the Indian subcontinent, Mexico, Central America and certain regions of Africa (Roumeliotis et al., 2012).

Childhood vitamin B12 deficiency is probably significantly more frequent than usually thought. Various studies carried 
out in the developing world or in countries where vegetarian diets are common have shown that a large number of mothers and children have low serum vitamin B12 levels that closely correlate with mild clinical problems mainly involving the central nervous system (Guez et al., 2012).

Vitamin B12 deficiency usually occurs in exclusively breastfed infants whose mothers have pernicious anaemia or are vegetarian leading to low body stores of vitamin B12 in the infant at birth and insufficient amounts of the vitamin in the breastmilk. Clinical manifestation of vitamin B12 deficiency in infants appears between 4 and 12 months of age and includes macrocytic anaemia, weakness, lethargy, irritability, feeding difficulties, failure to thrive, and neurodevelopmental regression (Kocaoglu et al.; 2014, Goraya et al., 2015).

The position statement on vegetarian diets points out that well-planned vegan and vegetarian diets are appropriate for all stages of the life cycle and offer a number of nutritional benefits, but it also notes that the use of fortified foods or supplements can be helpful in meeting dietary recommendations, especially in diets that completely exclude animal products (Elmadfa and Singer, 2009).

Early treatment of vitamin B12 deficiency in infants can prevent potentially neurologic and developmental sequelae (Roumeliotis et al., 2012).

\section{CASE REPORT}

A male child aged 13 months was hospitalized due to failure to thrive, feeding problems, pallor, weakness and hypotonia. The child was born in a term, at home and was not vaccinated. During the pregnancy mother did not eat meat and during lactation she also excluded eggs and milk. She did not use any supplementation. The child was exclusively breastfed. At the age of 6 months the mother attempted to introduce solid food, but the child refused. Deficiency of vitamin B12 was confirmed by subsequent examination of the mother. One child's grandmother suffered from anaemia and was receiving B12 vitamin therapy while the other one had leukaemia. The child manifested a neurode- velopmental delay with a loss in body weight of $3.100 \mathrm{~g}$ for 4 months. On admission to the hospital he was pale with a generalized hypotonia and systolic murmur grade 2. The liver edge was $2.5 \mathrm{~cm}$ below the costal margin. The splenic tip was palpable. His weight was $8,900 \mathrm{~g}$ ( $3^{\text {rd }}$ percentile $)$, length $79 \mathrm{~cm} \quad\left(3^{\text {rd }}\right.$ percentile), head circumference $46 \mathrm{~cm}$ $\left(50^{\text {th }}\right.$ percentile). Laboratory investigations showed a haemoglobin level of $3.5 \mathrm{~g} / \mathrm{dL}$, haematocrit $10 \%$, red blood count of 0.99 $\times 10^{12} / \mathrm{L}$ with $3.9 \%$ reticulocytes, white blood count of $4.23 \times 10^{9} / \mathrm{L}$ and platelet count of $55 \times 10^{9} / \mathrm{L}$. The mean corpuscular volume (MCV) was $102.5 \mathrm{fL}$. Foetalhaemoglobin was $2.1 \%$, serum iron $39.1 \mu \mathrm{mol} / \mathrm{L}$ (range 7.2-17.9), unsaturated iron binding capacity (UIBC) $18.5 \mu \mathrm{mol} / \mathrm{L}$ (range 27.863.6), total iron binding ca-pacity (TIBC) $57.6 \mu \mathrm{mol} / \mathrm{L}$ (range 39.4-80.6), serum ferritin $159.3 \mu \mathrm{g} / \mathrm{L}$ (range15-300). Homocysteine level was $10.8 \mu \mathrm{mol} / \mathrm{L}$ (range 512). LDH was elevated - 18.54 ukat/L (range 0-5.73). Total bilirubin was 42.2 $\mu \mathrm{mol} / \mathrm{L}$ (range 0.01-21), direct bilirubin 9.1 $\mu \mathrm{mol} / \mathrm{L}$ (range 0-5) and indirect bilirubin $33.3 \mu \mathrm{mol} / \mathrm{L}$ (range 0.01-16). Direct Coombs test was negative. Serum vitamin B12 level was $61.2 \mathrm{pmol} / \mathrm{L}$ (range 138652 ) and serum folate level $34.5 \mathrm{nmol} / \mathrm{L}$ (range 7-45.3). The blood smear showed anisocytosis with regular white blood cells and platelets. A bone marrow aspiration showed morphological changes consistent with megaloblastic anaemia. Immunofenotyping revealed no pathological hematopoietic cells. Karyotype was normal. The echocardiographic finding was normal. The computerized tomography (CT) and magnetic resonance imaging (MRI) of the endocranium showed global parenchymal reductive changes with consecutive enlargement of ventricles (Figs. 1, 2). Psychological testing revealed a delay in psychical development.

During the hospitalization the child received a transfusion of filtered red blood cells three times and a transfusion of platelet concentrates two times. After B12 deficiency was diagnosed, vitamin B12 therapy started. Vitamin B12 in a dose of 10 $\mu \mathrm{g}$ per $\mathrm{kg}$ was applied intramuscularly daily for 2 weeks, then once weekly. 


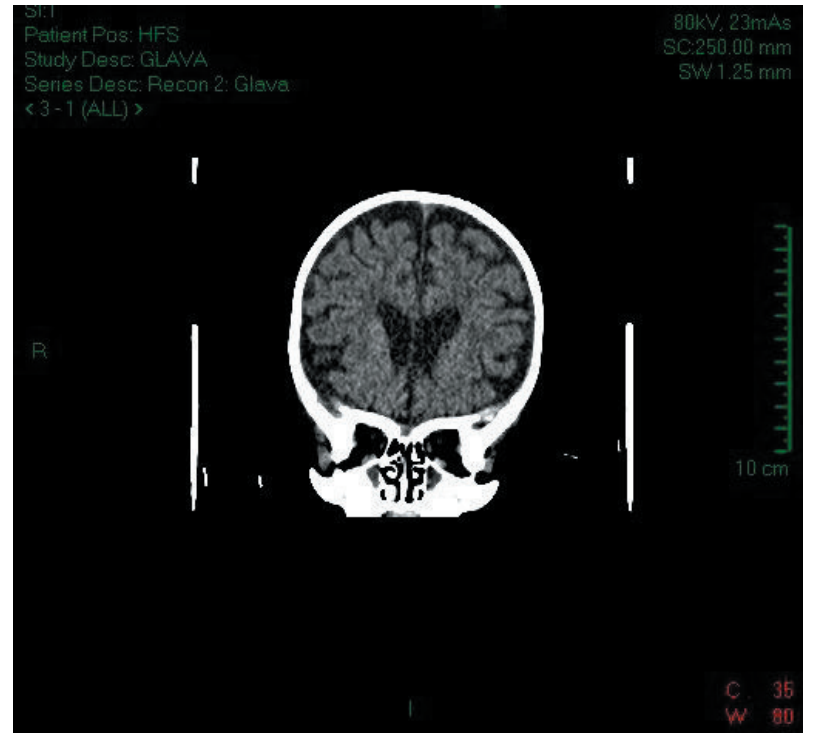

Figure 1. Magnetic resonance imaging (MRI) of the endocranium (MRI 1.5 T Signa HDx General Electric Medical Systems) - global parenchymal reductive changes with consecutive enlargement of ventricles

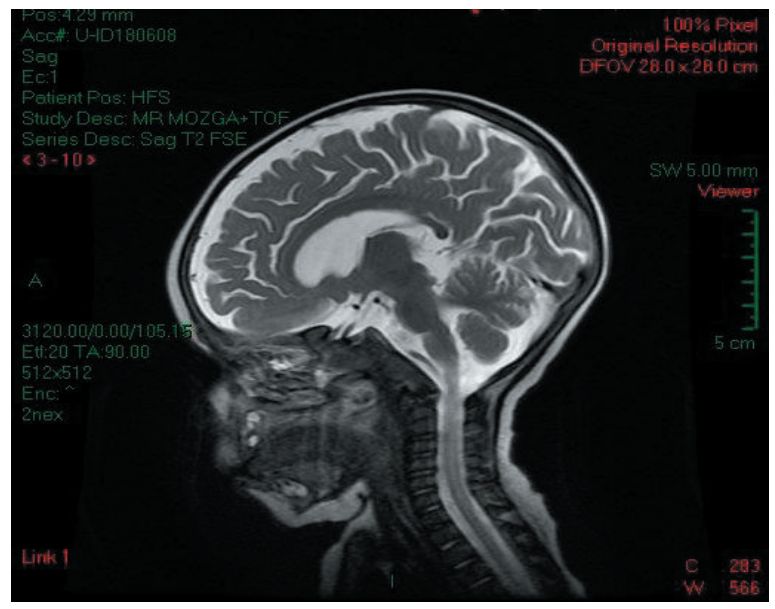

Figure 2. The computerized tomography (CT) of the endocranium - brain atrophy

Table 1.

Admission and follow-up clinical and laboratory data

\begin{tabular}{lcccc}
\hline Parameter & $\begin{array}{c}\text { On admission to } \\
\text { the hospital }\end{array}$ & $\begin{array}{c}\text { At the end of } \\
\text { hospitalisation }\end{array}$ & $\begin{array}{c}\text { A month after } \\
\text { discharge }\end{array}$ & $\begin{array}{c}\text { Three months } \\
\text { after discharge }\end{array}$ \\
\hline $\begin{array}{l}\text { Neurological } \\
\text { state }\end{array}$ & $\begin{array}{c}\text { severe hypotonia, } \\
\text { unable to sit or } \\
\text { stand }\end{array}$ & $\begin{array}{c}\text { mild hypotonia, } \\
\text { unable to sit or } \\
\text { stand }\end{array}$ & $\begin{array}{c}\text { mild hypotonia, } \\
\text { able to sit, unable } \\
\text { to stand }\end{array}$ & $\begin{array}{c}\text { adequate tonus, } \\
\text { able to sit and } \\
\text { stand }\end{array}$ \\
$\begin{array}{l}\text { Haemoglobin } \\
\text { (g/dL) }\end{array}$ & 3.5 & 13.6 & 15.8 & 12.9 \\
MCV (fL) & 102.5 & 88.9 & 79.9 & 74.8 \\
$\begin{array}{l}\text { White blood cell } \\
\text { count }\end{array}$ & 4.23 & 11.8 & 5.4 & 4.7 \\
$\begin{array}{l}\left.\text { (cells } \times 10^{9}\right) \\
\begin{array}{l}\text { Platelet count } \\
\left.\text { (cells } \times 10^{9}\right)\end{array}\end{array}$ & 55 & 248 & 318 & 359 \\
$\begin{array}{l}\text { Serum vitamin } \\
\text { B12 (pmol/L) }\end{array}$ & 61.2 & $>1475$ & $>1475$ & $>1475$ \\
\hline
\end{tabular}


Nutrition was initiated firstly through a nasogastric tube. In the further course the child began to accept meals. Three days after initiating B12 vitamin therapy there was an improvement in the blood count with the gradual improvement of neurological state and gaining in body weight. The child was discharged after a month of hospital treatment with a normal blood count and vitamin B12 value of more than $1475 \mathrm{pmol} / \mathrm{l}$. On the first ambulatory follow-up, 3 weeks after hospitalization, due to the elevated vitamin B12 values, further therapy was not continued. The child began to sit a month after hospitalization, and after 3 months he stood. He was active and in a good mood along with further gaining in body weight (Table 1). Control neuroradiological imaging was not conducted because of good clinical response.

\section{DISCUSSION}

Vitamin B12 is a relatively large and complex vitamin. It is an essential micronutrient that plays a fundamental role in cell division and in one-carbon metabolism. Vitamin B12 participates as a cofactor in two important intracellular metabolic reactions (Elmadfa and Singer,2009). Deoxyadenosylcobalamin, one of the coenzyme forms of cobalamin, is a cofactor for methionine synthase, the enzyme which converts homocysteine to methionine (Roumeliotis et al., 2012). The methionine synthase reaction is necessary for normal DNA synthesis (Elmadfa and Singer,2009). If this coenzyme is lacking, homo-cysteine accumulates, leading to megaloblastic anaemia and neurologic sequelae. Cobalamin is also a cofactor for methylmalonyl CoA mutase, the enzyme that converts methylmalonyl CoA to succinyl CoA, which plays an important role in the metabolism of odd-chain fatty acids and purine, and pyrimidine synthesis. Methylmalonic aciduria and defective amino acid synthesis results from the lack of the cobalamin cofactor, clinically leading to pancytopenia, metabolic acidosis and hypotonia (Roumeliotis et al., 2012).

Vitamin B12 is the only vitamin that is synthesized exclusively by microorganisms. Dietary sources are primarily of animal origin, including meats, dairy products, and eggs. It is not supplied by plant foods un- less they have been exposed to specific bacterial action. Thus, vegans and to a lesser degree other vegetarians are advised to use vitamin B12-fortified foods or supplements (Elmadfa and Singer, 2009; Stabler and Allen; 2004, Milankov, 2014; Kovač et al., 2013).

Cobalamin is actively transported across the placenta in foetuses of cobalamindeficient mothers, and infants of such mothers are haematologically normal at birth. However, their cobalamin stores are low and if they are exclusively breastfed, cobalamin deficiency will develop between 2 and 12 months of age, when stores have been depleted (Roumeliotis et al., 2012; Kocaoglu et al., 2014; Goraya et al., 2015; Pepper and Black, 2011; Zeeshan et al., 2017).

Infant vitamin B12 deficiency, in most cases, results from a maternal deficiency. Maternal causes of infant deficiency can be broadly divided into deficient maternal diet or maternal pernicious anaemia in a breastfed infant, because infant formulas are supplemented with B12. Other more rare causes in children include surgical removal of the stomach and/or distal ileum, autoimmune gastritis, bacterial overgrowth, ileal disease (Crohn disease), exocrine pancreatic insufficiency, and Whipple disease. Maternal dietary deficiency is usually due to poverty, vegetarian diet (which excludes meat and fish) or vegan diet (excluding also all dairy and eggs) (Roumeliotis et al., 2012; Elmadfa and Singer, 2009; Stabler and Allen, 2004; Milankov, 2014; Weiss et al., 2004). Mothers are often asymptomatic but have laboratory evidence of vitamin B12 deficiency (Goraya et al., 2015; Guez et al., 2012). In our patient vitamin B12 deficiency was caused by insufficient intake of the vitamin due to exclusion of meat, eggs and milk in mother's diet during pregnancy and lactation. In addition to that, the child aged 13 months was exclusively breastfed with no introduction of solid food, so breastmilk of a vegan mother, lacking vitamin B12, was the only nutritional source. Clinical manifestations of vitamin B12 deficiency in infants result from the affected hematopoietic, digestive and nervous systems. They include macrocytic anaemia, 
pallor, weakness, lethargy, irritability, feeding difficulties with aversion to or refusal of solid food, failure to thrive and neurodevelopmental regression (Roumeliotis et al., 2012; Goraya et al., 2015; Weiss et al., 2004). All these symptoms were present in our patient. Other findings include glossitis, vomiting, diarrhoea, icterus, oedema, convulsions, repeated infections, sudden nose bleed, bruises and petechiae without any history of trauma (Roumeliotis et al., 2012; Goraya et al., 2015; Weiss et al., 2004; Codazzi et al., 2005; Baatenburg et al. 2005; Reghu et al. 2005). Deficiency of vitamin B12 may affect the central nervous system and, in severe cases, cause brain atrophy (Kocaoglu et al., 2014; Goraya et al., 2015; Guez et al., 2012; Codazzi et al., 2005; Wagnon et al. 2005). Head circumference measurements fall off the growth curve, indicating slowing of brain growth. Patients progress to hypotonia with hyperreflexia, and exhibit abnormal movements such as tremor, myoclonus and choreoathetoid movements (Roumeliotis et al., 2012; Codazzi et al., 2005; Goraya et al., 2015). Rarely this deficiency may cause coma, hypothermia and respiratory failure requiring ventilation. Neurodevelopmental regression may lead clinicians on the wrong path searching for neurodegenerative disorders or inborn errors of metabolism resulting in unnecessary investigation and inappropriate delay in treatmentof vitamin B12 deficiency (Goraya et al., 2015).The mechanisms of central nervous system involvement are not clearly understood. Demyelination, impaired methylation and lactate accumulation in peripheral nerves, spinal cord and cerebrum have all been proposed (Roumeliotis et al., 2012). Neurodevelopmental delay was present in our patient, while CT and MRI of the endocranium showed global parenchymal reductive changes. The haematological manifestation of vitamin B12 deficiency is megaloblastic anaemia with high MCV and typical morphological features, such as large erythrocytes with anisocytosis and poikilocytosis and hyperlobulation of the nuclei of the granulocytes. In advanced cases, neutropaenia and thrombocytopaenia may occur; simulating aplastic anaemia or leukaemia (Kocaoglu et al., 2014; Citak and Citak, 2011).The diag- nosis of vitamin B12 deficiency is confirmed by determining serum vitamin B12 concentration. In our patient a pancy-topaenia was detected. The diagnosis of megaloblastic anaemia was made based on high MCV and bone marrow biopsy findings. Low serum vitamin B12 confirmed vitamin B12 deficiency.

Treatment of vitamin B12 deficiency should start as soon as possible, because the neurological sequelae can be corrected. Most clinical features of vitamin B12 deficiency resolve quickly with repletion of vitamin B12 (Weiss et al., 2004; Guez et al., 2012). This was confirmed in our case where three days after initiating B12 vitamin therapy an improvement in the blood count and neurological state was detected. The neurologic findings generally improve within weeks, and MRI of the brain returns to normal within a few months. Long-term neurodeficit such as psychomotor and linguistic delay have been reported (Roumeliotis et al., 2012; Goraya et al., 2015; Codazzi et al., 2005). The overall prognosis depends on duration of deficiency and severity of symptoms rather than serum levels of vitamin B12 or haemoglobin values on admission. It seems that infants diagnosed and treated before one year of age have more favourable neurological outcome than those treated at a later period (Kocaoglu et al., 2014).

There are recommendations for initial and maintenance therapy of vitamin B12 deficiency in adults but no clear guidelines are available for children. In adults with severe B12 deficiency with neurologic manifestations, experts recommend $1000 \mu \mathrm{g}$ cyanocobalamin given via intramuscular injection daily for a week, followed by weekly injections for a month, then every third month. Consensus guidelines for optimal replacement therapy in deficient paediatric patients are required. Replacement therapy at adult doses was described in a number of articles (Roumeliotis et al., 2012; Kocaoglu et al., 2014; Guez et al., 2012; Baatenburg et al. 2005; Citak and Citak, 2011). In our patient, vitamin B12 was given in the dose $10 \mu \mathrm{g} / \mathrm{kg}$ daily for 2 weeks, then weekly for a month. Then the therapy was stopped because of the high 
serum level of vitamin B12. Further clinical observation included control blood counts and determination of serum level of vita$\min \mathrm{B} 12$.

\section{CONCLUSIONS}

Vitamin B12 deficiency is a treatable cause of pancytopenia and neurological dysfunction in children and should be considered as differential diagnosis in an infant with neurological symptoms, especially if megaloblastic anaemia is present. In order to prevent it, clinician's caring for pregnant or lactating mothers and their newborns should take a full dietary history and consider vitamin B12 status. In pregnant and breastfeeding women on a vegetarian or vegan diet B12 supplements should be recommended. Our case highlights the need to carefully plan the diet and use a supplementation during the pregnancy and lactation either in vegetarian or vegan mothers in order to prevent negative health repercussion to both a mother and her child.

\section{ACKNOWLEDGEMENTS}

This work was supported by the Ministry of Education and Science, Serbia, Grant numbers: III 46012 and III 41012.

Parental consent was obtained to the publication of medical data within this case study.

\section{REFERENCES}

1. Baatenburg de Jong, R., Bekhof, J., Roorda, R., Zwart, P. (2005). Severe nutritional vitamin deficiency in a breast-fed infant of a vegan mother. European Journal of Pediatrics, 164 (4), 259-260.

2. Codazzi, D., Sala, F., Parini, R., Langer, M. (2005). Coma and respiratory failure in a child with severe vitamin $\mathrm{B}(12)$ deficiency. Pediatric Critical Care Medicine, 6 (4):483-485.

3. Citak, F.E., Citak, E.C. (2011). Severe vitamin B12 deficiency in a breast fed infant with pancytopenia. Journal of Tropical Pediatrics, 57 (1), 69-70.
4. Elmadfa, I., Singer, I. (2009). Vitamin B-12 and homocysteine status among vegetarians: a global perspective. American Journal of Clinical Nutrition, 89 (supplement), 1693S-1698S.

5. Goraya, J.S., Kaur, S., Mehra, B. (2015). Neurology of nutritional vitamin B12 deficiency in infants: case series from India and literature review. Journal of Child Neurology, 30 (13), 18311837.

6. Guez, S., Chiarelli, G., Menni, F., Salera, S., Principi, N., Esposito, S. (2012). Severe vitamin B12 deficiency in an exclusively breastfed 5month-old Italian infant born to a mother receiving multivitamin supplementation during pregnancy. BMC Pediatrics, 12, 85, DOI: 10.1186/1471-2431-12-85.

7. Kovač, D., Simeunović, J., Babić, O., Mišan, A., Milovanović, I. (2013). Algae in food and feed. Food and Feed Research, 40 (1), 21-31.

8. Kocaoglu, C., Akin, F., Çaksen, H., BuğraBöke, S.,Arslan, Ş., Aygün, S. (2014). Cerebral atrophy in a vitamin B12-deficient infant of a vegetarian mother. Journal of Health Population and Nutrition, 32 (2), 367-371.

9. Milankov, O. (2014). Vegetarijanska ishrana odojčadi. Medicinski pregled, 67 (1-2), 5-10.

10. Pepper, M.R., Black, M.M. (2011). B12 in fetal development. Seminars in Cell and Developmental Biology, 22 (6), 619-623.

11. Reghu, A., Hosdurga, S., Sandhu, B., Spray, C. (2005). Vitamin B12 deficiency presenting as oedema in infants of vegetarian mothers. Europen Journal of Pediatrics, 164 (4), 257-258.

12. Roumeliotis, N., Dix, D., Lipson, A. (2012). Vitamin B12 deficiency in infants secondary to maternal causes. Canadian Medical Association Journal, 184(14), 1593-1598.

13. Stabler, S.P., Allen, R.H. (2004). Vitamin B12 deficiency as a worldwide problem. Annual Review of Nutrition, 24, 299-326.

14. Zeeshan, F., Bari, A., Farhan, S., Jabeen, U., Rathore, A.W. (2017). Correlation between maternal and childhood VitB12, folic acid and ferritin levels. Pakistan Journal of Medical Science, 33 (1), 162-166.

15. Weiss, R., Fogelman, Y., Bennett, M. (2004). Severe vitamin B12 deficiency in an infant associated with a maternal deficiency and a strict vegetarian diet. Journal of Pediatric Hematology/Oncology, 26 (4), 270-271.

16. Wagnon, J., Cagnard, B., Bridoux-Henno, L., Tourtelier, Y., Grall, J.Y., Dabadie, A. (2005). Breastfeeding and vegan diet. Journal de Gynecologie, Obstetriqueet Biologie de la Reproduction (Paris), 34 (6), 610-612. 


\section{ДЕФИЦИЈЕНЦИЈА Б12 ВИТАМИНА КОД ДЕТЕТА МАЈКЕ НА ВЕГАНСКОЈ ИСХРАНИ}

Олгица Б. Миланков ${ }^{* 1,2}$, Милена Р. Бјелица ${ }^{1,2}$, љиљана Ђ. Сувајџић ${ }^{3}$, Јасмина М. Максић ${ }^{4}$, Васја М. Миланков ${ }^{1}$, Деана Д. Медић ${ }^{1,5}$, Небојша М. Илић ${ }^{6}$

${ }^{1}$ Универзитет у Новом Саду, Медицински факултет, 21000 Нови Сад, Хајдук Вељкова 3, Србија

${ }^{2}$ Институт за здравствену заштиту деце и омладине Војводине, Клиника за педијатрију, 21000 Нови Сад, Хајдук Вељкова 10, Србија

${ }^{3}$ Универзитет у Новом Саду, Медицински фракултет, Департман за фармацију, 21000 Нови Сад, Хајдук Вељкова 3, Србија

${ }^{4}$ Универзитет у Београду, Факултет за специјалну едукацију и рехабилитацију, 11000 Београд, Студентски трг 1, Србија

${ }^{5}$ Институт за јавно здравље Војводине, Центар за микробиологију, 21000 Нови Сад, Футошка 121, Србија

${ }^{6}$ Универзитет у Новом Саду, Научни институт за прехрамбене технологије у Новом Саду, Булевар цара Лазара 1, Србија

Сажетак: Дефицијенција Б12 витамина се обично јавља код одојчади која су на природној исхрани а чије мајке имају пернициозну анемију или су вегетаријанци. Правовремено лечење дефицијенције Б12 витамина код одојчади може да превенира потенцијалне неуролошке последице. Мало мушко дете узраста 13 месеци је хоспитализовано због ненапредовања, проблема са храњењем, бледила, слабости и хипотоније.Током трудноће мајка није јела месо док је током дојења из исхране искључила и јаја и млеко. Дете је искључиво дојено. У лабораторијским налазима ниво хемоглобина је износио 3,5 г/дл, хематокрит $10 \%$, број еритроцита је био $0.99 \times 10^{12} /$ Л, број леукоцита $4.23 \times 10^{9} / /$ и број тромбоцита $55 \times 10^{9} /$ Л. Ниво Б12 витамина је био снижен. Налаз биопсије костне сржи указивао је на мегалобластну анемију. На магнетној резонанци ендокранијума виђена је атрофија мозга. Витамин Б12 у дози од 10 микрограма/кг примењен је интрамускуларно свакодневно током 2 недеље, потом једном недељно.Три дана од започињања терапије забележено је побољшање хематолошких вредности уз постепено побољшање неуролошког статуса. Дефицијенција Б12 витамина је узрок панцитопеније и неуролошке дисфунције код деце коју је могуће лечити. Код одојчета са неуролошким симптомима ова дефицијенција треба да буде размотрена као диференцијална дијагноза.

Кључне речи: мегалобластна анемија, дете, вегетаријанска исхрана, заостајање у развоју, атрофија мозга

Received: 10 May 2019

Received in revised form: 22 September 2019

Accepted: 2 October 2019 